Published in "Catena 72(2): 248-258, 2008"

which should be cited to refer to this work.

\title{
Application of ash (Fraxinus excelsior L.) roots to determine erosion rates in mountain torrents
}

\author{
O.M. Hitz ${ }^{\mathrm{a}, *}$, H. Gärtner ${ }^{\mathrm{b}}$, I. Heinrich ${ }^{\mathrm{a}}$, M. Monbaron ${ }^{\mathrm{a}}$ \\ ${ }^{a}$ University of Fribourg, Department of Geosciences, Geography, Chemin du Musée 4, 1700 Fribourg, Switzerland \\ ${ }^{\mathrm{b}}$ Swiss Federal Institute for Forest, Snow and Landscape Research WSL, Zürcherstrasse 111, 8903 Birmensdorf, Switzerland
}

\begin{abstract}
Due to the effect of global change, the potential risk of natural hazards occurring in alpine areas is expected to increase to an even higher risklevel than has been recorded during the last century. These global changes potentially also have distinct influences on fluvial processes in torrents causing erosion on slopes and riverbanks in forested areas. Dating the time of root exposure along riverbanks combined with common dendrogeomorphic analysis applied to tree trunks helps to reconstruct the erosion dynamics leading to a potential destabilization of adjoining trees. The advantage of using exposed roots compared to common erosion measurement techniques is that the erosion rates can be quantified with annual resolution. The first year of exposure can be determined precisely by the characterization of the wood anatomical changes in the microscopic structure of the root. This study is the first to concentrate on the analysis of wood anatomical features of exposed roots of angiosperm trees aiming to reconstruct erosional processes. Two mountain torrents were selected as study sites based on a preliminary evaluation of various Swiss alpine areas. Sites of special interest concerning erosive processes were classified and examined in five different geomorphological groups representing different processes. The analysis comprised the examination of the exposed tree roots in each group. The project shows the potential of roots in general and in particular roots of deciduous angiosperm trees for geomorphological research, especially concerning erosion studies.
\end{abstract}

Keywords: Roots; Erosion; Dendrogeomorphology; Wood anatomy; Tree rings; Switzerland

\section{Introduction}

In the last decades, Switzerland has been highly affected by natural hazards. In alpine areas, various geomorphic processes, such as landslides or debris flows occurred frequently causing severe damage to existing infrastructure in the affected areas. These damages increase the need for detailed analyses of erosional behaviour of mountain torrents and their capacity as a medium to transport materials. Due to the effect of global change (IPCC, 2001a,b), the potential risk of natural hazards occurring in alpine areas is likely to increase to an even higher risk-level than has been recorded during the last century (PLANAT, 2004). These global changes potentially also have distinct influences on fluvial processes in torrents causing erosion on slopes and riverbanks even in forested areas.

\footnotetext{
* Corresponding author. Tel.: +412630092 50; fax: +41263009746.

E-mail address: oliver.hitz2@unifr.ch (O.M. Hitz).
}

The Swiss Confederation has subsidised forest management procedures along mountain torrents influenced by intensive erosional processes. Denudation as well as continuous and discontinuous erosion of forested riverbanks frequently causes structural destabilization of hillslopes and a potential tree fall of riparian trees. As a secondary process landslides may occur frequently affecting trees along the torrents. Fallen trees may cause a blockage of the fluvial system and in case of a collapse of these dams severe floodings or even debris-flow surges may occur. Consequently, a potential threat to human life and infrastructure caused by erosive processes exists and hence needs to be estimated (BUWAL, 1998).

Protective actions in forests along alpine torrents so far have concentrated mostly on cutting down bigger trees growing along the riverbanks of the torrents to lower the risk of uprooting due to erosional processes (Wasser and Frehner, 1996). These actions aim to reduce the risk of deadwood and consequential blockages within the torrents. 
In dendrogeomorphology (Alestalo, 1971) annual variations of growth rings and their morphology are used as indicators to characterize geomorphic processes both spatially and temporally (Bodoque et al., 2005). In many studies, tree-ring analysis has been used to provide the calendar date of geomorphic events as well as the season of the year of their occurrence (Wiles et al., 1996). The majority of dendrogeomorphological studies focused on the characterisation of tree trunks but only to a lesser extent roots have been used.

Generally, erosion rates can be obtained by measuring the lowering of the ground surface against a datable reference such as tree roots. The main advantage of this method is the availability of tree-ring records in contrast to common measuring devices producing data after costly installations (Lawler, 2005).

Eardley and Viavant (1967) and LaMarche (1968) showed that erosion rates can be measured from the degree of tree-root exposure. Both studies investigated denudation on slopes bare of soil and forest litter. In the rangelands of Kenya, extreme erosion rates cause root exposure of young trees and small bushes even on gentle slopes (Dunne et al., 1978). Carrara and Carroll (1979) investigated hillslope erosion in the Piceance basin of Colorado. Bodoque et al. (2005) analysed sheet erosion in Spain and Pelfini and Santilli (2006) examined erosion along two mountain hiking trails in the Italian alps. Vandekerckhove et al. (2001) looked at gully erosion in soft deposits at the footslopes of limestone hill in southeast Spain. Recently, Malik (2006) studied meandering bank erosion using root exposure. Shore erosion along a lake in Italy was reconstructed by Fantucci (2007).

The advantage of using exposed roots compared to common erosion measurement techniques is that the erosion rates can be quantified with an annual resolution. This method of obtaining proxy erosion rates is subject to several problems of interpretation and measurement error, but the problems can be reduced by technical precision (Bodoque et al., 2005).

Roots of trees do not develop without substrate - they need soil to anchor and grow. The terminal, water-absorbing, parts of the root system only work properly in the soil; they die when exposed. This implies that an exposed part of a living root situated in a gully is older than the gully at the corresponding location (Vandekerckhove et al., 2001). The age of roots at the time of initial cambial reduction from the shape and continuity of the growth rings has been estimated (LaMarche, 1963). Usually, the typical vertical buttress-form results when bark and cambium are stripped off from the upper root surface and secondary growth continues on the lower side. This implies that the time since exposure can only be determined when the root is still alive. The method used to determine erosion rates from exposed roots is based on the change in the ring-growth pattern from concentric to eccentric due to exposure. The quotient defined by the vertical distance between the upper part of the root and the present ground surface, and the time since exposure, offers an estimate of the erosion rate in $\mathrm{mm} / \mathrm{year}$ (LaMarche, 1963, 1968; Eardley and Viavant, 1967; Carrara and Carroll, 1979; McCord, 1987; Danzer, 1996).

In addition to shifts from concentric to eccentric growth patterns, reaction wood and wood anatomical changes in the rings occur. As Gärtner et al. (2001) state, a series of anatomical changes occur due to both the effects of exposure (e.g. variations of temperature, reduction of pressure of soil cover, light incidence, etc) and the mechanical stress that the root undergoes when it loses its edaphic cover continuously and progressively. The first year of exposure can be determined precisely by the characterization of the wood anatomical changes in the microscopic structure of the root (e.g., width of the growth ring, number of cells per ring, percentage of latewood, diameter of cellular lumen in earlywood). The occurrence of reduced cell lumen dimensions of about $50 \%$ has been identified as a distinct signal for conifers that a large part of the root has been exposed (Gärtner et al., 2001; Gärtner, 2003).

Many common tree species (e.g. Fraxinus excelsior L., Acer pseudoplatanus L., Ulmus spp, Fagus sylvatica L., Abies alba Mill., Picea abies Karsten, Taxus baccata L.) can live for several decades or even centuries. Consequently, tree-ring analysis can be a valuable tool to date geomorphic events such as landslides in regions lacking detailed historical records. Treering analysis is used to determine growth reactions in trees corresponding to geomorphic processes. This opens new perspectives on the erosional behaviour of the torrents in the past on an annual time scale.

Dating the time of root exposure along riverbanks combined with common dendrogeomorphic analysis applied to tree trunks may help to reconstruct the erosion dynamics leading to a potential destabilization of adjoining trees. The analysis of growth reactions in trees indicating movements of the ground allows to evaluate the stability of these trees and to estimate their potential to become a source of dangerous driftwood in a future event.

For the first time, a central focus is set on the analysis of wood anatomical features of exposed roots of deciduous angiosperm trees for the reconstruction of erosional processes in alpine torrents.

\section{Study site}

The selection of two mountain torrents ("Brüggenwaldbach" Gersau, Canton of Schwyz and "Steinibach" - Flühli, Canton of Luzern) was based on an evaluation of Swiss alpine areas according to the basic requirements for the presented study (Figs. 1 and 2). These requirements were, e.g., high recent fluvial dynamics, steep slopes, a catchment area smaller than $8 \mathrm{~km}^{2}$, the presence of riparian trees and the occurrence of roots exposed by fluvial erosion.

Riparian forests at both torrents as well as the adjacent forests are composed of conifers and deciduous trees. Thus, it is most likely to find roots of conifers and deciduous trees which were exposed by the same event. In this case, the aim was to use the exposed roots of conifers as a control to determine anatomical changes in exposed deciduous roots. Furthermore, riparian trees at the chosen sites are older then 50 years, which facilitates the dating of older landslide events. Both torrents are densely forested along their slopes and their catchment areas contain more than $50 \%$ forested area. All stands are more or less homogenous regarding minimal disturbances caused by, e.g., wind-break and management actions. The torrents are characterized by a high capacity to transport coarse woody debris and driftwood is present in the riverbeds. There are no man-made 


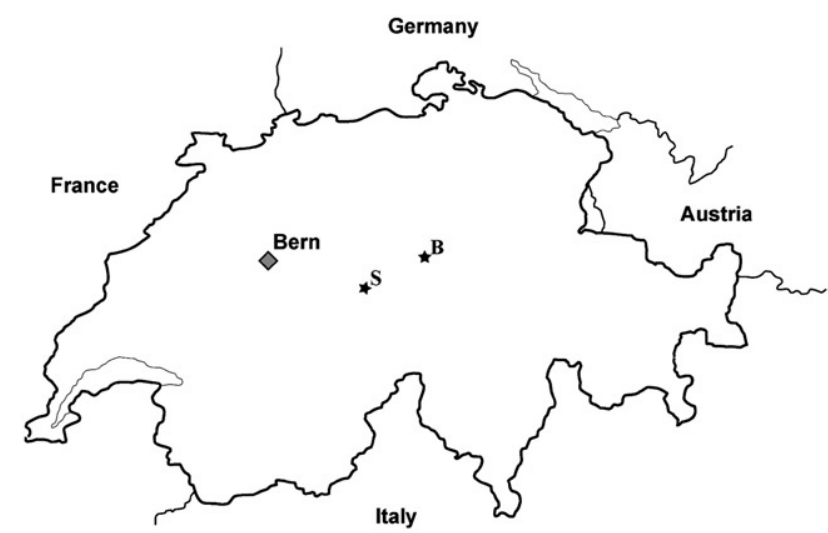

Fig. 1. Location of the study sites Brüggenwald $\mathbf{B}$ (Schwyz), and Steinibach $\mathbf{S}$ (Luzern), in Switzerland.

constructions in the torrents for the stabilization of riverbanks or riverbeds. In the last decades, both torrents caused severe damage to infrastructure through various flooding events.

Table 1 lists specific descriptors of the two torrents. Although both torrents have mostly steep slopes on both sides (Fig. 2) and similar geological and climatic site patterns, they differ regarding their channel geometry, flooding potential, drainage area, topography and composition of riparian forests (i.e., tree diameter and height, tree species).

\section{Materials and methods}

3.1. Geomorphic mapping of the torrents and adjacent hillslopes

Along the course of each torrent a sector spanning $1 \mathrm{~km}$ was selected for comprehensive analyses. Within these sectors the

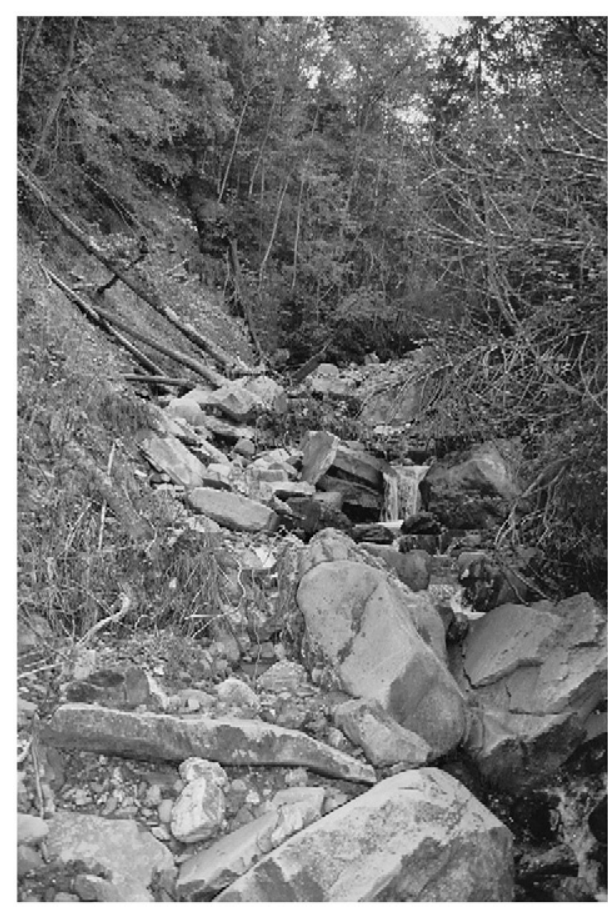

Fig. 2. Typical situation with respect to forest cover, coarse woody debris and slope angles along the riverbank of the study site Steinibach. course of the torrent channel was mapped, profiles were measured every $100 \mathrm{~m}$ and geomorphic mapping (scale 1:1000) was conducted. Besides the general dimensions of the riverbed, specific zones showing signs of accumulation and erosion as well as specific characteristics of the surrounding area such as slope angle and density of forest cover were documented in detail.

In this study five main processes listed in Table 2 were examined along the torrents. The first process "riverbank erosion" is the most important and dominant process leading to the exposure of tree roots. Riverbank erosion leads to lateral erosion which is the main trigger for landslides, the second process exposing roots. The third process "landslides on slopes" differs from the second process type because here landslides are not caused by undercutting processes but by the sheer steepness of the slope. The fourth process type "denudational processes" slowly exposes roots by means of splash and sheet erosion, scouring erosion or soil creep. The fifth process type is linear erosion on the slopes mainly due to rainfall run-off.

Five different processes were analysed by two dendrogeomorphological dating methods, that is, the analysis of (i) growth anomalies in the stem of disturbed trees and (ii) anatomical variations in exposed roots.

Table 1

Characteristics of the mountain torrents Steinibach and Brüggenwaldbach

\begin{tabular}{lll}
\hline & Steinibach & Brüggenwaldbach \\
\hline Similarities & & \\
Catchment area & $4 \mathrm{~km}^{2}$ & $2.5 \mathrm{~km}^{2}$ \\
Elevation above sea level & $1100-1900$ & $700-1600$ \\
$\begin{array}{l}\text { Degree of afforestation } \\
\text { Species structure }\end{array}$ & $50 \%$ & $65 \%$ \\
Degree of intervention & Mixed stand & Mixed stand \\
& No interventions & Sparse or no \\
interventions
\end{tabular}


Table 2

Characteristics of the different processes taking place in the studied torrents

\begin{tabular}{|c|c|c|c|c|c|}
\hline & Riverbank erosion & Landslides caused by riverbank erosion & Landslides on slopes & Denudation on slopes & Linear erosion \\
\hline Velocity of the process & Indefinite & Fast & Fast & Slow & Indefinite \\
\hline Location of the process & Riverbed & Riverbed & Riverine slopes & Riverine slopes & Tributary \\
\hline Reference for dating & Root & Root, stem & Stem & Root & Root \\
\hline Number of sites Brüggenwaldbach & 8 & 2 & 2 & 1 & 1 \\
\hline Number of sites Steinibach & 15 & 11 & 2 & 3 & 2 \\
\hline
\end{tabular}

As the anatomical analysis of the wood does not differ for these different processes, only processes two and five (landslides caused by lateral erosion and related landslides) will be illustrated exemplarily in the results section. Table 2 also indicates which dendrogeomorphological reference (exposed root or reaction wood in stems) was used for dating purposes and where these processes took place. In the following, the two processes are shortly described and illustrated:

\subsection{Landslides caused by lateral erosion}

Fig. 3 shows a typical landslide caused by undercutting processes. Riverbank erosion destabilized the adjacent slope causing smaller landslides. Exposed roots can be found on the initial crack which is predominantly located several meters above the riverbed. These landslides frequently occur in one event so the roots have been exposed suddenly. At these locations, cores of stems were sampled in addition to the roots for further dating.

\subsection{Linear erosion on slopes}

The process type concerns erosion in ravines, gullies and rills flowing into the channel. Their occurrence is also closely linked to rainfall and consequently also sporadic. If there is heavy rainfall, the erosion potential rises and the gullies increase in depth and in length as a result of retrograde erosion. Normally, only grains are removed continuously from the bank face or the

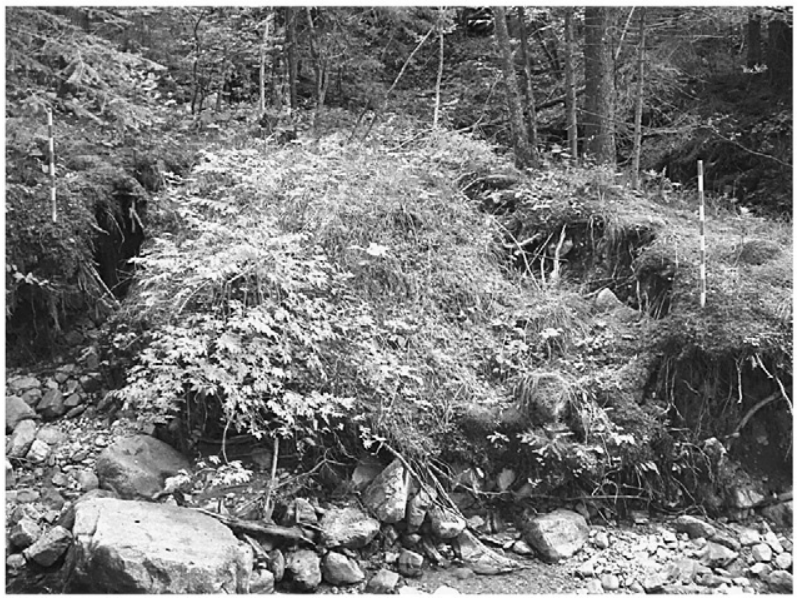

Fig. 3. Undercutting processes of the lateral riverbanks can cause landslides. In addition to the exposed roots, all tree stems influenced by these landslides on the lower section of the slope were core-sampled. channel sole and there are no stronger processes like mass failures. This type of site is often not in direct contact with the torrent but at a few meters distance from the riverbank (see Fig. 4).

\section{Sampling strategy}

Trees displaying exposed roots obviously influenced by erosional processes along the riverbanks were of special interest for the analysis of the erosion dynamics at the sites. Consequently, their dimensions and orientations were documented and their close environments mapped in detail (scale 1:100). The detailed mapping of these specific sites included the measurement of profiles and a precise documentation of the position of the exposed roots related to the recent soil surface. The vertical distance between the upper and lower part of the root and the present soil surface was measured, taking measurements on both ends of the exposed root section in order to determine maximum, minimum and average distances. A detailed description of the spatial and morphological characteristics of the root's environment (up to $3 \mathrm{~m}^{2}$ ) was prepared. Where these specific sites were frequent, the entire section was measured and mapped in detail (Fig. 5). Site locations containing exposed roots of both coniferous and deciduous trees were preferred because the anatomical reactions due to exposure are already known for conifers (Gärtner et al., 2001) and hence acted as a reference to determine anatomical changes in roots of angiosperm trees.

In addition to these sites concentrating on exposed roots, mass movement processes were also mapped in detail. For dating these mass movements trunks of obviously influenced (tilted) trees were cored upslope and downslope. Ring width variations were measured to an accuracy of $1 / 100 \mathrm{~mm}$, accurately dated according to dendrochronology standard procedures (e.g., Cook and Kairiukstis, 1990). The resulting chronologies were then checked against a reference chronology of the area and further analysed for eccentric growth and the formation of reaction wood.

\section{Wood anatomical analysis of exposed roots}

Disc samples were taken from exposed roots at all sites of interest and their respective positions were marked in the documented profiles. At each position two discs were sampled, one for macroscopical analysis of ring-width variations and the second for preparing micro slides to analyse anatomical variations (Gärtner, 2003). Sections of exposed roots were obtained at a minimum distance of $1 \mathrm{~m}$ away from the trunk because at shorter distances exposure might be more related to 


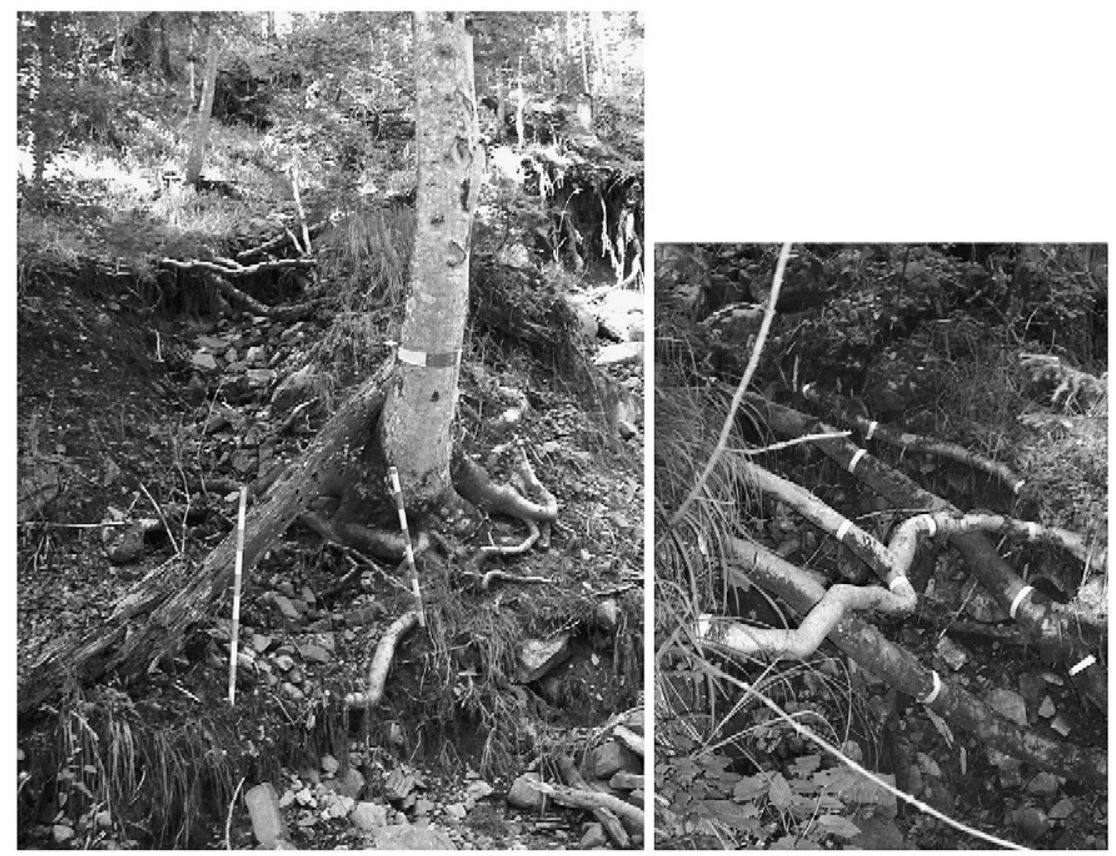

Fig. 4. Typical site of gully erosion increasing in depth, width and length. The gully functions as an intermittent tributary to the torrent (foreground of image). Zoom image illustrates typical gully erosion with resulting exposure of roots.

tree growth and hence more influenced by stem-related mechanical stress. Mechanical stress causes a change of cell dimensions (reaction wood) which also leads to eccentric growth of tree rings (Mattheck and Breloer, 1992). Discs of unexposed parts of each root were also taken to compare anatomical details in relation to the exposed parts. The root sampling at both locations was done during the growing seasons between 2003 and 2005 .

As only living roots were sampled, it was plausible that the last growth ring corresponded to the year in which sampling took place. The dating of the ring series by simply counting the rings of one radius introduces some degree of uncertainty and thus the tree-ring analysis was conducted on four radii on disc samples in order to minimise uncertainties due to false, wedging or missing rings.

In coniferous root samples the lumen size of earlywood cells were measured each year. For deciduous species a comparable procedure was applied. The anatomical structure of deciduous trees is more complex than the structure of coniferous trees and several cell types assume different functions. The analysis concentrated on possible variations in the anatomical structure of vessels and fibre cells as well as on differences in earlywood and latewood. However, the lumen size of fibre cells of selected angiosperm trees has recently been identified as the most important wood anatomical indicator to reveal root exposure of selected deciduous angiosperm tree species (Hitz et al., in review).

\section{Results}

The results for the process groups "landslide caused by lateral erosion" and "gully erosion" are described below.

\subsection{Dating of a landslide caused by lateral erosion using spruce stems and roots}

Fig. 6 shows the annual growth rings of a spruce standing near the edge of a slope of a landslide caused by undercutting erosion activity of the river below (process type 2). The graphs of the down- and upslope increment illustrate remarkable differences. The tree shows increased growth on the downslope side and at the same time decreased growth on the upslope side beginning in 1982. In addition to this eccentricity the tree also began to form reaction wood in the same year. Both reactions signalize that the tree started to lean due to slope instability; hence, the start of the mass failure event was dated to 1982 .

In addition to the changes in the stem wood, the root samples are of special interest. Fig. 7 shows an exposed coniferous root (P. abies (L.) Karst.) with an abrupt reduction in cell lumen dimensions in the earlywood between the end of 1995 and the beginning of 1996 strongly suggesting this as the first time of exposure. This distinct change in cell size can be attributed to a sudden exposure of the root due to an intense erosional event at the specific location. A detailed analysis of the cell size distribution within the earlywood of the respective year enabled even an intra-annual dating of the exposure. The first two to three cell layers in the earlywood of 1996 display cell lumina that are comparable to the cell lumina in 1995 and before. The following rows of earlywood cells show a remarkable reduction in size, hence, it was deduced that the exposure started in the early growing period of 1996. In 1997 a reduction of cell lumen size of approximately $50 \%$ within the entire earlywood range in relation to the long-term average of 1971 to 1995 occurs. Consequently it was determined that the ring 1997 was formed 


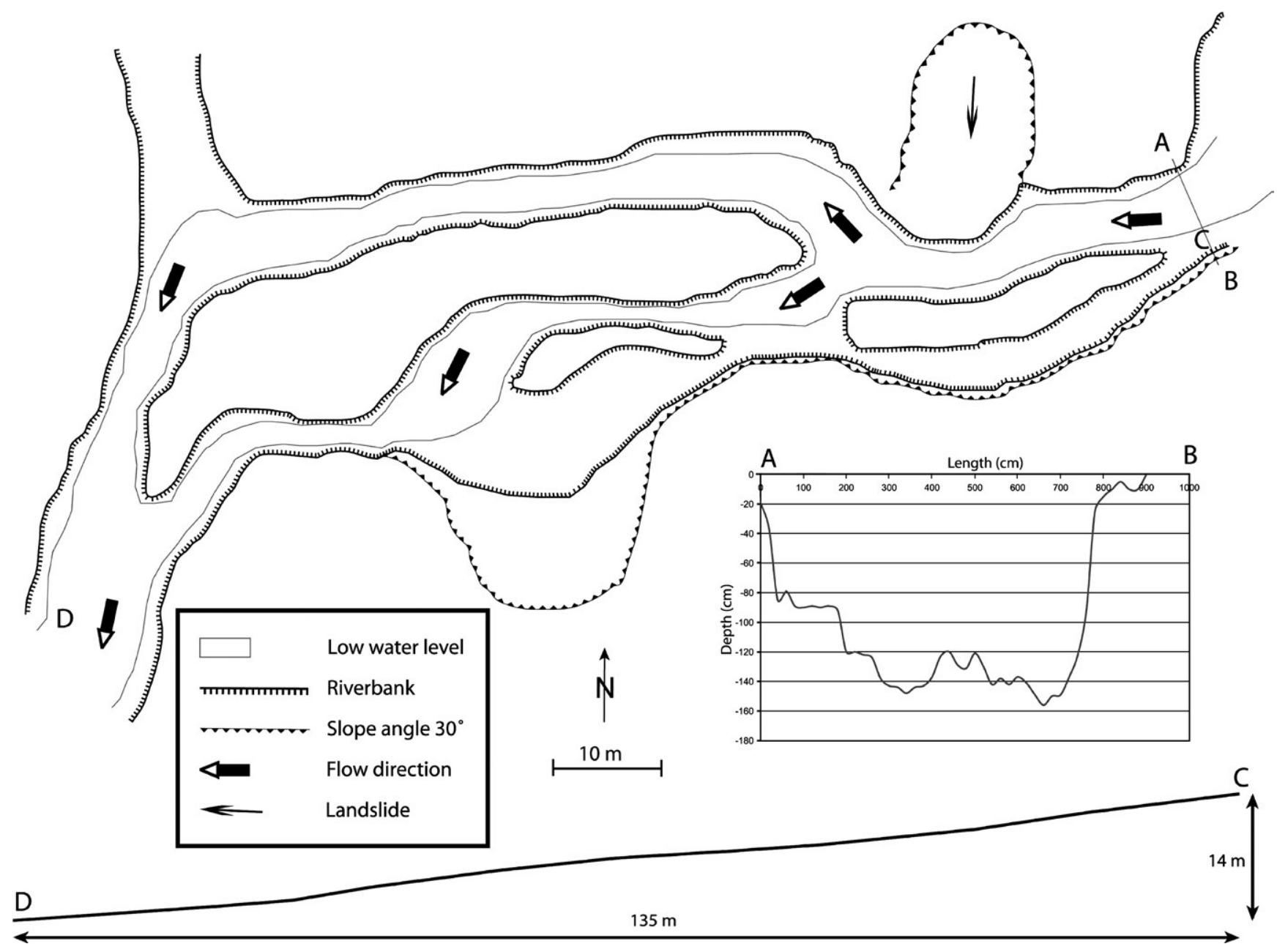

Fig. 5. A detailed map of a selected section along the upper Steinibach; the measurements contain profiles along and across the torrent.

after root exposure. Combining these findings with the geomorphological mapping of the location, it was possible to determine local erosion rates since 1996 shown below in Table 3.

\subsection{Reconstructing gully erosion using roots of European ash trees}

For the deciduous species, best results were found for ash ( $F$. excelsior L.). In Fig. 8, the micro section of an exposed root of

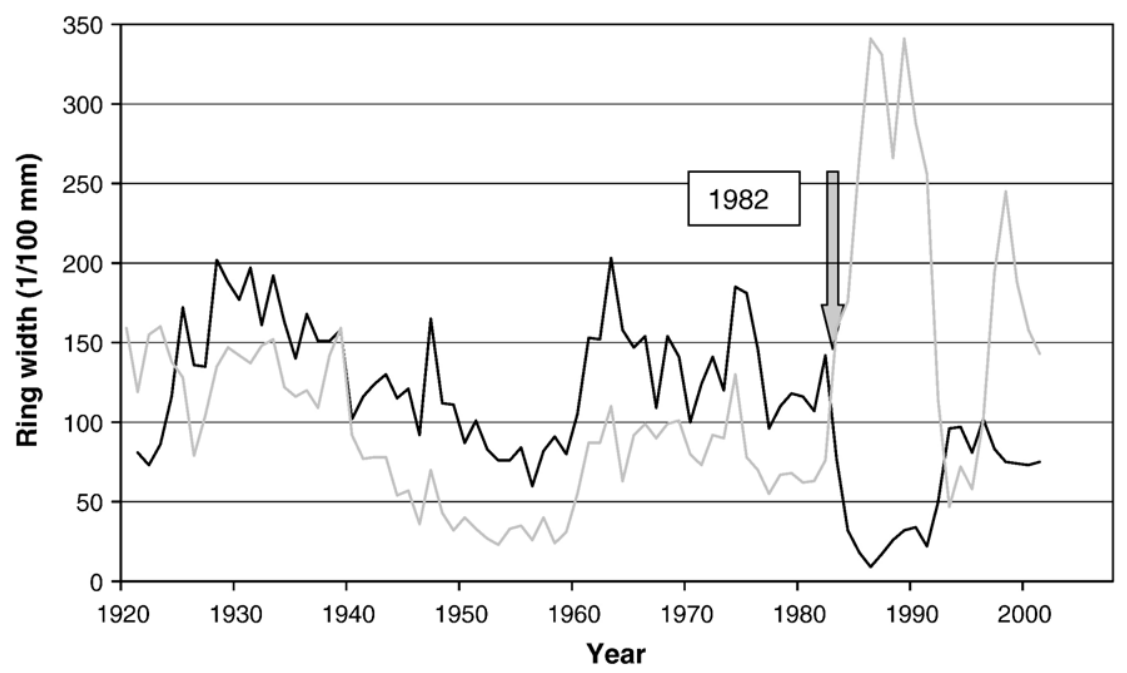

Fig. 6. Downslope (grey) and upslope (black) growth increments of a spruce (Picea abies (L.) Karst.) growing near the edge of a mass movement caused by undercutting processes at the study site Steinibach. Arrow indicates 1982 as the likely event year. 

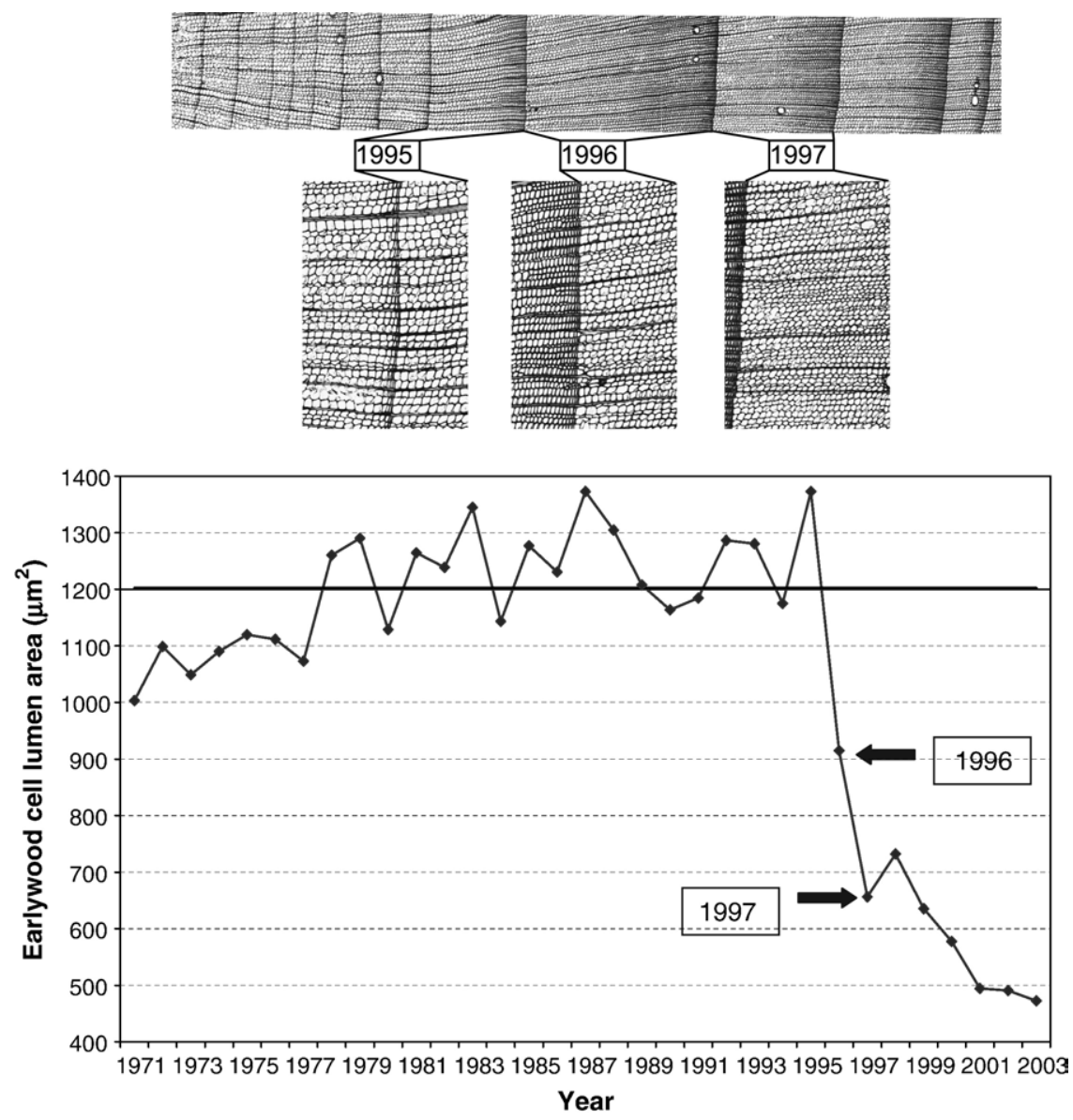

Fig. 7. Micro section (above) taken from a coniferous root (Picea abies (L.) Karst.) disc with the corresponding graph (below) showing annual values of the mean lumen area of earlywood cells (black) and the long-term average of 1971 to 1995 (horizontal grey line). Arrow indicates 1997, the first tree ring after root exposure.

an ash tree shows a change in the overall structure. The appearance of the outer rings is darker than near the centre of the root. In the innermost part of the root the fibre cells have thin cell walls and big cell lumen areas. In addition, it is difficult to differentiate between earlywood and latewood. In the outer part of the root the cell lumen area is reduced and cell walls are thickened, hence the generally darker colour. In contrast to the innermost rings, an obvious change from earlywood to latewood is detectable. Furthermore, differences with respect to the vessel characteristics between the inner- and outermost rings are also discernible. Large vessels concentrate along the tree-ring boundary in the earlywood part. Within the innermost rings the number of vessels is higher and their lumen area is bigger compared to the outermost part. Near the bark, the latewood is dominated by small vessels which are missing in the inner part of the root.

Furthermore, fibre cells were measured (Fig. 9) and the measurements reveal similar trends with abrupt changes of the fibre cell lumen area, a reaction comparable to that found in coniferous roots. Fig. 9 illustrates this reaction, e.g., the variations of the fibre cell dimensions (black graph) indicate that three reductions have occurred, one in 1968 a second in 1987 and a third in 1997. In 1997 the lumen size of the fibre cells is reduced to approximately $50 \%$ of the long-term average (1960 to 1986) which strongly indicates that 1997 is the first growth ring after root exposure. In 1968 and 1987, cell lumen reductions also occur but they are restricted to only 1 year and the cell lumen measurements recover afterwards. A comparison

Table 3

Rates of erosion listed per type of process

\begin{tabular}{|c|c|c|c|c|c|}
\hline & Riverbank erosion & $\begin{array}{l}\text { Landslides caused by } \\
\text { riverbank erosion }\end{array}$ & $\begin{array}{l}\text { Landslides } \\
\text { on slopes }\end{array}$ & $\begin{array}{l}\text { Denudation } \\
\text { on slopes }\end{array}$ & $\begin{array}{l}\text { Linear } \\
\text { erosion }\end{array}$ \\
\hline Number of sites Brüggenwaldbach & 8 & 5 & 2 & 1 & 1 \\
\hline Number of sites Steinibach & 15 & 11 & 2 & 3 & 2 \\
\hline Erosion rate $(\mathrm{cm} /$ year) Brüggenwaldbach & 2.10 & 6.26 & - & 2.5 & 1.03 \\
\hline Erosion rate $(\mathrm{cm} /$ year) Steinibach & 1.86 & - & - & 0.90 & 4.44 \\
\hline
\end{tabular}




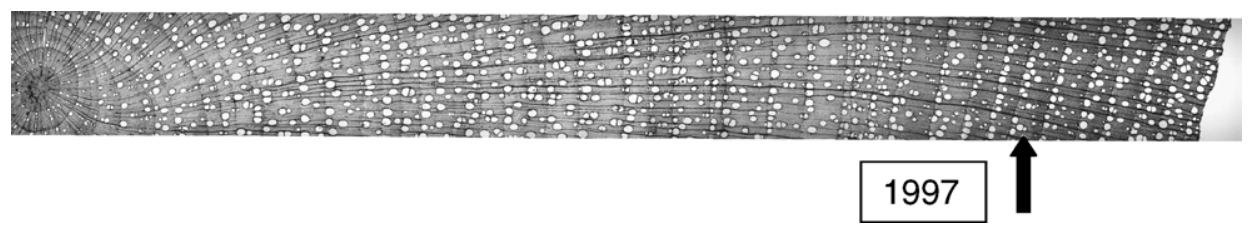

Fig. 8. Micro section taken from an exposed ash root (Fraxinus excelsior L.). Note that the overall structure appears darker near the bark and the vessel distribution changes from the innermost part (large vessels are spread over the entire tree ring, diffuse porous) to the outermost part (large vessels concentrate along the tree-ring boundary in the earlywood part, mostly ring porous). Arrow indicates 1997 as the first year after exposure (see also Fig. 9).

of the tree-ring structures in Fig. 8 reveals that the reductions are caused by small annual rings generally containing smaller fibre cells. Only the sustained reduction of fibre cell lumen areas to approximately $50 \%$ below the long-term average of the previous years indicates an exposure.

The 4 years before the proposed year of exposure in 1997 are remarkable because, contrary to the sample of the spruce root shown in Fig. 7, the reduction in fibre cell lumen areas appears to be continuous from 1993 to 1997 indicating an equally continuous root exposure within this timespan. This feature indicates, that only the top edge of the root was exposed in 1993 (compare Fig. 10), which is a likely explanation for the relatively weak reaction. Afterwards erosion continued until the whole circumference of the root was exposed in 1997 as the resulting stepwise reduction in fibre cell lumen area indicates.

Concerning the rate of erosion two different phases are distinguishable in Fig. 10: in the first phase, slow continuous erosion with an erosion rate of approximately $1 \mathrm{~cm} /$ year happened between 1993 and 1997 followed by a second phase characterized by higher erosion rates of approximately $6.5 \mathrm{~cm} /$ year occurring from 1997 to 2004 . However, after full exposure in 1997 no further direct information is available from the root wood anatomy about the second phase which may have included both continuous and discontinuous erosion. Taking into account that the root is situated in a gully, it is most likely that one or more high precipitation events occurred resulting in increased discontinuous erosion. This assumption is supported by the precipitation data available for the area. The amount of precipitation during winter 1996/97 and spring 1997 was exceptionally low followed by one of the wettest summers on record in 1997 indicating that a high precipitation event in summer 1997 was responsible for the total exposure of the root. This was followed by above-average annual precipitation between 1999 and 2002 (Fig. 11) likely to be the reason for the higher rate of erosion between 1997 and 2004.

The analyses of the exposed roots delivered two different kinds of results, that is, an event date which was also supported by analysing growth anomalies in the stem. It indicates the year when the mass failure or the erosional event took place. Secondly, continuous erosional processes were dated and reconstructed by analysing exposed tree roots and finally the rate of erosion was calculated. Table 3 lists erosion rates derived from the analysis of growth anomalies in the stem as well as in exposed roots for the two torrents investigated in this study. The rates reconstructed for the two torrents differ markedly. While the linear erosion compared to the denudation on slopes is relatively weaker in Brüggenwaldbach, the opposite is true for Steinibach. This variation is difficult solely to explain by differences in slope steepness since the slopes in Brüggenwaldbach are even steeper which theoretically should support more linear erosion. However, differences in forest stand structures, geology, erosion dynamics and the profiles and

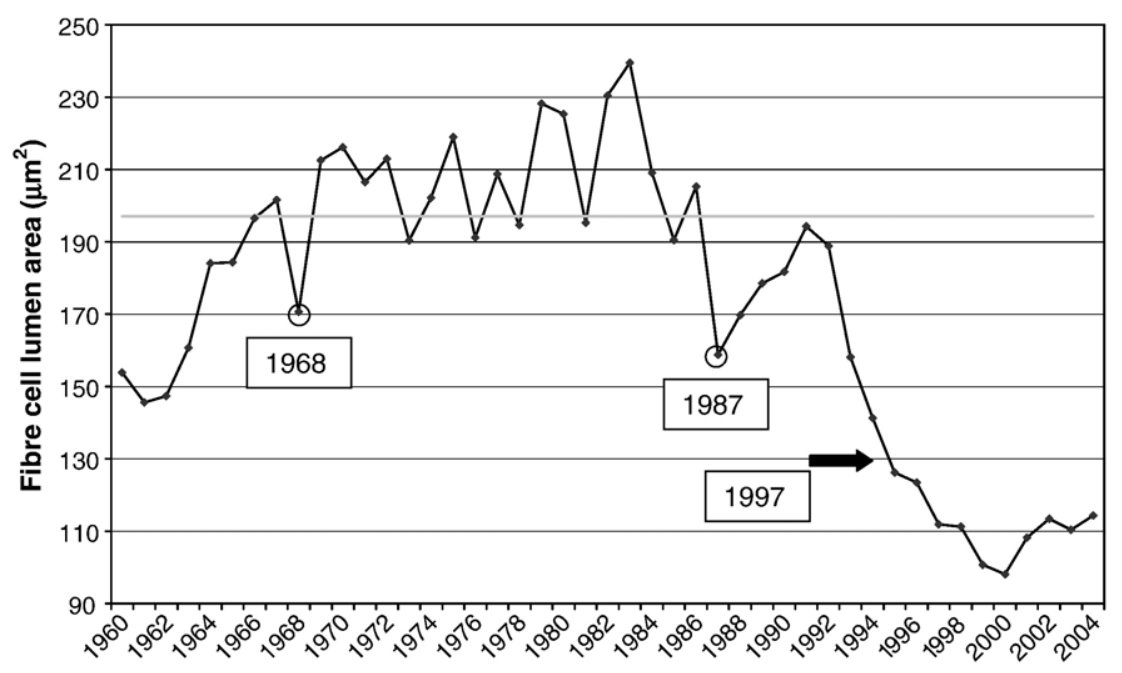

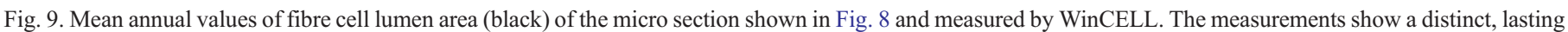

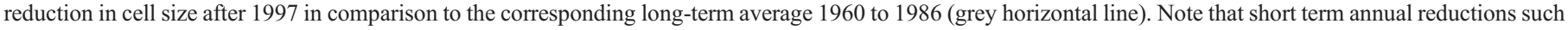
as those for 1968 and 1987 are caused by extremely narrow rings, which naturally show smaller fibre cells. 


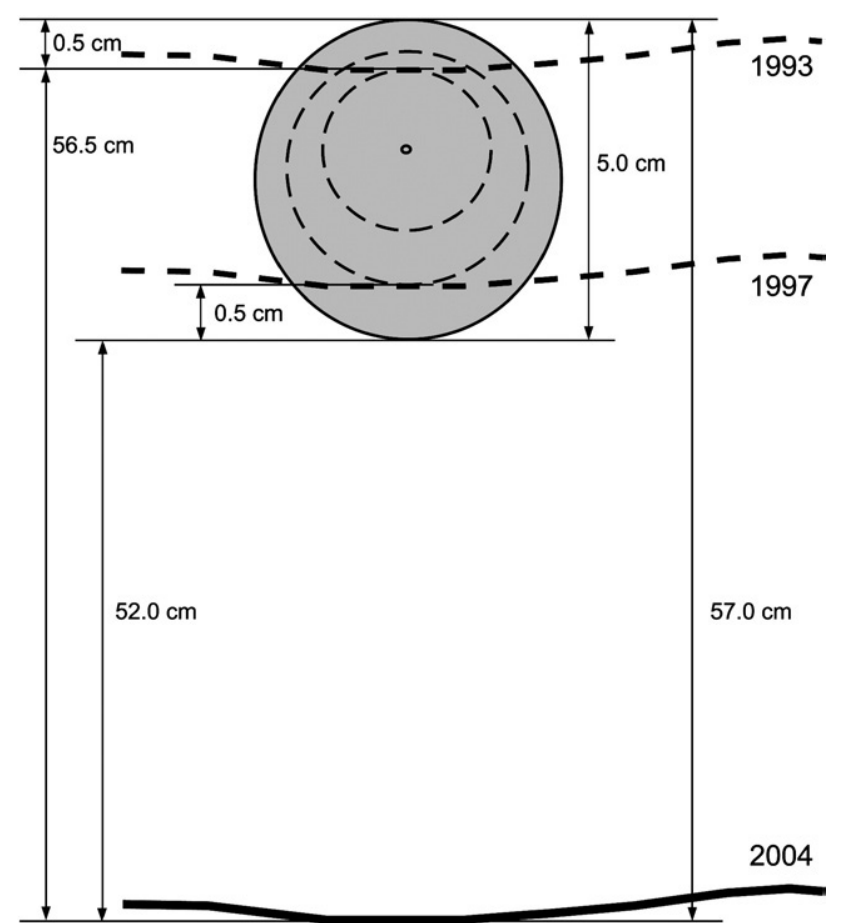

Fig. 10. Cross-sectional view of an ash root situated in a gully (illustrated also in Figs. 8 and 9). The bold and dashed lines show the actual soil surface (2004) and their reconstructed locations in 1993 and 1997, respectively. The dashed lines within the cross-section of the root (grey) indicate the tree rings for the years 1993 and 1997, during which the root was exposed continuously (see also Fig. 9).

courses of the torrents might be responsible for the distinct erosion rates.

While the dating of intense erosion events was feasible the dating of slowly exposed roots was not always successful, especially of angiosperm species often growing in the riverine slopes. Since these roots were only exposed by very slow splash or sheet erosion (process 4), further analyses need to be conducted to define more comprehensively the specific wood structural anomalies occurring during slow angiosperm root exposure.

\section{Discussion}

\subsection{Dating the exposure of roots}

In his pioneering work concerned with the study of roots and their growth, Fayle (1968) conducted growth experiments exposing and burying roots and compared their anatomy with those of roots grown without disturbances. He was able to characterize several changes in the anatomy of roots due to exposure. Several other authors used these changes to date different processes of root exposure (LaMarche, 1968; Morneau and Payette, 1998). Most of them used conifer roots and applied changes in the overall shape (eccentricity) or the occurrence of compression wood as indicators to date exposure. Gärtner et al. (2001) used anatomical techniques to analyse the process of exposure and the wood anatomical reaction of conifer roots. He found that the shape of a root (and also other indicators) already began to change near the soil surface even before the exposure of the root. He also found that the earlywood cell lumen size was a reliable indicator for exposure because the earlywood cell lumen size was changing after exposure. The presented study also used earlywood cell lumen size as an indicator for exposure and confirmed the results found by Gärtner et al. (2001).

In addition to the coniferous roots, also roots of deciduous angiosperm trees were analysed. Their wood structure is more complex thus containing different cell types. In a first study, vessels and fibre cells were analysed (Hitz et al., in review). It was shown that fibres and vessels often react similarly although vessels are predominantly built for water transport, while the fibres main function is to stabilize the tree. Since vessel characteristics in stem wood have been found to be good

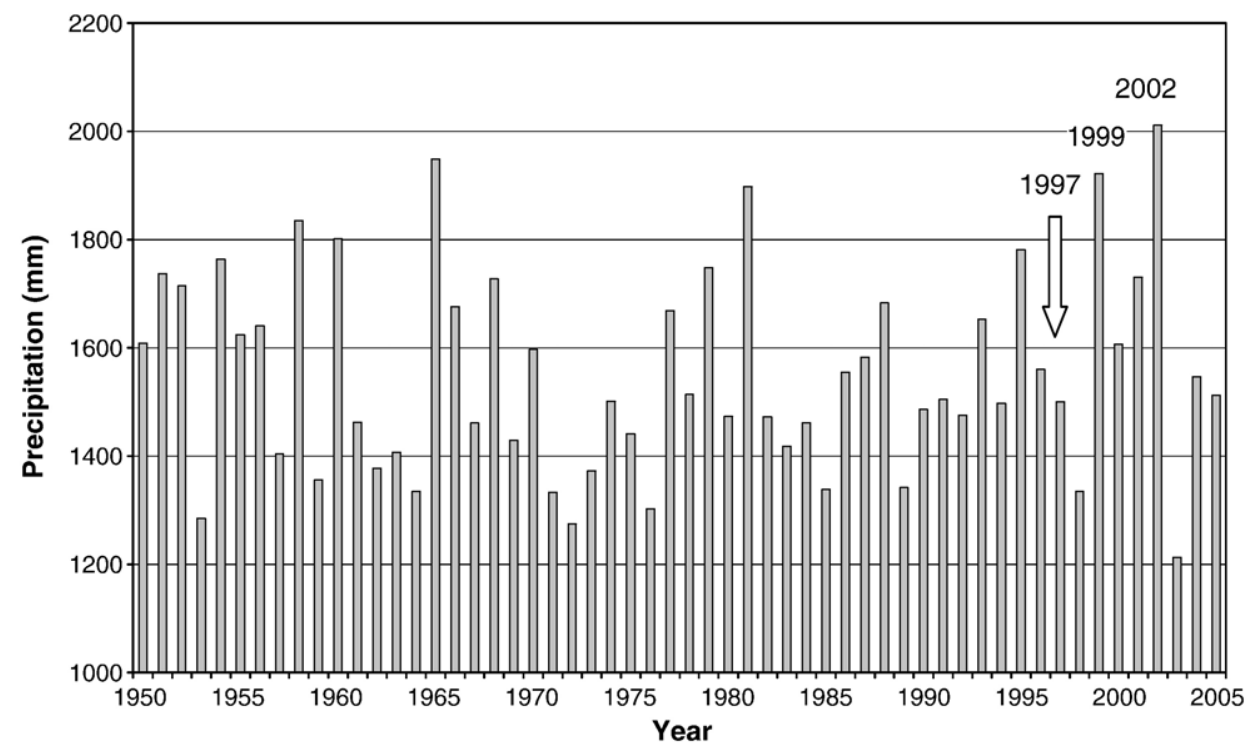

Fig. 11. Annual precipitation sum (1950-2005) from station Engelberg representing both study sites Steinibach and Brüggenwaldbach. 
indicators for rainfall variations, the current analyses concentrated more on fibre cells.

When conifers grew next to angiosperms simultaneous reactions were found, which indicates that the distinct reactions found in angiosperm roots (especially in roots of ash trees) occurred because of exposure and not due to variations in precipitation.

The results have shown that roots of ash (F. excelsior L.) can be used similarly to roots of conifers to determine local erosion rates. When roots of angiosperm and coniferous trees were growing side by side it was possible to crosscheck the dating, the roots of the coniferous trees always confirming the year of exposure identified by exposed roots of the angiosperms. However, some of the root samples of other deciduous tree species showed indistinct and mostly not countable tree rings limiting the application of the method only to selected species.

\subsection{Dating different types of erosion}

The analyses of the exposed roots delivered two different kinds of results, that is, an event date which was also supported by analysing growth anomalies in the stem. It indicates the year when the mass failure or the erosional event took place. Secondly, continuous erosional processes were dated and reconstructed by analysing exposed tree roots and finally the rate of erosion was calculated. Table 3 lists erosion rates derived from the analysis of growth anomalies in the stem as well as in exposed roots for the two torrents investigated in this study. The rates reconstructed for the two torrents differ markedly. While the linear erosion compared to the denudation on slopes is relatively weaker in Brüggenwaldbach, the opposite is true for Steinibach. This variation is difficult to explain by differences in slope steepness only since the slopes in Brüggenwaldbach are even steeper which would normally support more linear erosion. However, differences in forest stand structures, geology, erosion dynamics and the profiles and courses of the torrents might be responsible for the distinct erosion rates.

While the dating of intense erosion events was feasible the dating of slowly exposed roots was not always successful, especially of angiosperm species often growing in the riverine slopes. Continuous erosion processes exposing the roots of these trees often did not result in distinct reactions and hence it seems as if the continuous lowering of the soil surface happening over a period of several decades is yet not exactly quantifiable. Further research on the anatomical variations in roots of angiosperm trees is needed to shed more light on the variety of possible reactions and to fully explore the potential of wood anatomy in angiosperms for dendrogeomorphological analyses.

\section{Conclusions}

Generally, the results imply that it is possible to determine wood anatomical reactions in roots of broadleaf species due to root exposure. These reactions of roots can be used as a new dating tool to reconstruct the exact year of exposure and hence of erosional processes in vegetation zones dominated by angiosperms. Due to the complex and specialised structure of angiosperm wood it might also hold more information than coniferous wood and thus might deliver further details on the processes of root exposure and the different erosion processes (continuous or discontinuous erosion).

The first results obtained in this study confirmed the usefulness and importance of dendrogeomorphological studies, that is, regarding the dating of river erosion and landslides as sources of environmental risk and its importance for the establishments of proxy records in areas, where historical records are scarce. By providing annual to intra-annual data, the study demonstrated that dendrogeomorphology is a helpful discipline to those concerned with the study of landscape evolution.

\section{Acknowledgements}

The authors wish to thank Christian Rickli, Hansueli Bucher, Tobias Meyer and Raphael Holland for their support in the field. Furthermore we wish to thank the Swiss Agency for the Environment, Forests and Landscape (SAEFL/BUWAL) for funding the project.

\section{References}

Alestalo, J., 1971. Dendrochronological interpretation of geomorphic processes. Fennia 105, 1-139.

Bodoque, J.M., Diez-Herrero, A., Martin-Duque, J.F., Rubiales, J.M., Godfrey, A., Pedraza, J., Carrasco, R.M., Sanz, M.A., 2005. Sheet erosion rates determined by using dendrogeomorphological analysis of exposed tree roots: two examples from central spain. Catena 64, 81-102.

BUWAL, 1998. Methoden zur Analyse und Bewertung von Naturgefahren. Umwelt-Materialien, vol. 85. Bundesamt für Umwelt, Wald und Landschaft.

Carrara, E., Carroll, T.R., 1979. The determination of erosion rates from exposed tree roots in the Piceance Basin, Colorado. Earth Surf. Processes 4, 307-317.

Cook, E.R., Kairiukstis, L.A. (Eds.), 1990. Methods of Dendrochronology: Applications in the Environmental Science. International Institute for Applied Systems Analysis. Kluwer Academic Publishers, Dordrecht.

Danzer, S.R., 1996. Rates of slope erosion determined from exposed roots of ponderosa pine at Rose Canyon Lake, Arizona. In: Dean, J., Meko, D.M., Sewtnam, T.W. (Eds.), Tree Rings, Environment, and Humanity. Radiocarbon 1996, Proceedings of the International Conference, University of Arizona, Tucson, pp. 671-678.

Dunne, T., Dietrich, W.E., Brunengo, M.J., 1978. Recent and past erosion rates in semi-arid Kenya. Z. Geomorphol. N.F., Suppl.Bd 29, 130-140.

Eardley, A.J., Viavant, W., 1967. Rates of denudation as measured by Bristlecone Pines, Cedar Breaks, Utah. Utah Geol. Miner. Surv., Spec. Stud. 21, 3-13.

Fantucci, R., 2007. Dendrogeomorphological analysis of shore erosion along Bolsena lake (Central Italy). Dendrochronologia 24, 69-78.

Fayle, D.C.F., 1968. Radial Growth in Tree Roots - Distribution, Timing, Anatomy. Technical Report, vol. 9. Faculty of Forestry, Universitiy of Toronto.

Gärtner, H., 2003. Holzanatomische Analyse diagnostischer Merkmale einer Freilegungsreaktion in Jahrringen von Koniferenwurzeln zur Rekonstruktion geomorphologischer Prozesse. Diss. Bot. 378, 1-118.

Gärtner, H., Schweingruber, F.H., Dikau, R., 2001. Determination of erosion rates by analyzing structural changes in the growth pattern of exposed roots. Dendrochronologia 19, 1-11.

Hitz, O.M., Gärtner, H., Heinrich, I., Monbaron, M., in review. Reconstruction of erosive processes in mountain torrents by exposed tree roots. Dendrochronologia.

IPCC, Climate Change 2001, 2001a. The Scientific Basis: A Contribution of Working Group I to the Second Assessment Report of the Intergovernmental Panel of Climate Change. Cambridge University Press. 
IPCC, Climate Change 2001, 2001b. Synthesis Report: A Contribution of Working Group I, II and III to the Third Assessment Report of the Intergovernmental Panel of Climate Change. Cambridge University Press.

LaMarche, V.C., 1963. Origin and geologic significance of buttress roots of bristlecone pines, White Mountains, California. U.S. Geol. Surv. Prof. Pap. 475-C, C148-C149.

LaMarche, V.C., 1968. Rates of slope degradation as determined from Botanical Evidence White Mountains California. Geol. Surv. Prof. Pap. 352-I.

Lawler, D.M., 2005. The importance of high-resolution monitoring in erosion and deposition dynamics studies: examples from estuarine and fluvial systems. Geomorphology 64, 1-23.

Malik, I., 2006. Contribution to understanding the historical evolution of meandering rivers using dendrochronological methods: example of the Mala Panew River in southern Poland. Earth Surf. Processes Landf. 31, 1227-1245.

Mattheck, C., Breloer, H., 1992. Root cross-sections tell the load history. Allg. Forst-Jagdztg. 163 (7-8), 142-145.

McCord, V.A.S., 1987. Late Holocene sediment yield and transport in a northern Arizona drainage basin reconstructed by tree-ring analysis. In:
Jacoby Jr., G.C., Hornbeck, J.W. (Eds.), Proceedings of the International Symposium on Ecological Aspects of Tree-ring Analysis, 1986, New York, pp. 213-223.

Morneau, C., Payette, S., 1998. A dendroecological method to evaluate past caribou (Rangifer tarandus L.) activity. Ecoscience 5 (1), 64-76.

Pelfini, M., Santilli, M., 2006. Dendrogeomorphological analyses on exposed roots along two mountain hiking trails in the Central Italian Alps. Geogr. Ann., Ser. A 88 (3), 223-236.

PLANAT, 2004. Strategie Naturgefahren Schweiz Synthesebericht, vol. 81

Vandekerckhove, L., Muys, B., Poesen, J., De Weerdt, B., Coppé, N., 2001. A method for dendrochronological assessment of medium-term gully erosion rates. Catena 45, 123-161.

Wasser, B., Frehner, M., 1996. Wegleitung Minimale Pflegemassnahmen für Wälder mit Schutzfunktion. Vollzug Umwelt. Bundesamt für Umwelt, Wald und Landschaft.

Wiles, G.C., Calkin, P.E., Jacoby, G.C., 1996. Tree-ring analysis and Quaternary geology: principles and recent applications. Geomorphoplogy 16, 259-272. 